\title{
A Tracer Study on Business Administration Program Outcomes
}

\author{
Kingie G. Micabalo and Ryan D. Montilla \\ University of Cebu, Cebu City, Philippines \\ E-mail: kmicabalo@uc.edu.ph,rmontilla@uc.edu.ph
}

\begin{abstract}
Program Outcomes speak to comprehensive explanations that consolidate numerous zones between related information and aptitudes created over the program's span of broad scope of courses and encounters. This investigation assesses the realization of the Business Administration Program Outcomes for the Year 2015-2019. The respondents were 673 alumni from the University of Cebu- Lapu Lapu and Mandaue. Descriptive survey method was utilized as an examination instrument on snowball sampling. The discoveries uncovered program outcomes that (1) meets the current demand and needs of the industry in the areas of human resource, marketing, accounting, and finance; (2) Communicate and collaborate effectively; and (3) Adhere strictly to professional, ethical standards were realized by the alumni understudies. Program outcomes: (4) Contribute to socio-economic development and environmental sustainability; and (5) Utilizing information technology were less realized. The examination concluded that business management research-based guidelines ought to be actualized and continued. Outcome-Based Teaching and Learning ought to be received to empower understudies to create aptitudes required in the course. Community services spreading business and management development should be adjusted each semester to guarantee maintainability in community vocation programs. Furthermore, Progression of mechanical approach to managing training and learning requests to improved adaption on the new trend and innovations of the money managers and business people.
\end{abstract}

keywords: Business administration, program outcomes, descriptive study, Cebu City, Philippines

\section{INTRODUCTION}

Program outcomes are measurements from the HEI (Higher Education Institution), which quantifies the current educational program's viability. It speaks to broad explanations that join numerous zones between related information and aptitudes created over the program's term through a broad scope of courses and encounters. They talk to a higher perspective, portray complete parts of conduct, and include various learning encounters. The results must cover a dream of ideal alumni for the program and oblige previous objectives (Lewis et al., 2009).

Learning results speak to one of the basic structure blocks for straightforward advanced education frameworks and capabilities. A vital component in new capability systems is the detail of learning results. The result can be classified and indicated in different manners. Generally, advanced education about the information to accomplish or covered by the educational plan. The capability descriptor speaks to depicting quantifiable pointers of learning results and accomplishments the understudy needs to show for the granted capability (Hammond et al., 2004). Productive arrangement' is usually followed when working up an OBE prospectus. It is a term authored by Professor John Biggs, which alludes to a learning climate cycle underpinning the learning exercises suitable for accomplishing the ideal learning results. The word 'productive' implies what the student does to build significance through practical learning exercises. The 'arrangement' perspective alludes to what the educator does. The way into the arrangement is that the parts in the showing framework, particularly the training strategies utilized and the appraisal adjusted to the learning exercises accepted in the proposed results (Biggs, 2003).

Further, result based educating and learning underscore the express assertion of learning results that recognize the undertakings understudies ready to perform after finishing the course. Outcome-based instructing and adapting require educating, learning, and appraisal exercises to line up with the expressed learning results (Au and Kwan 2009).

The business Administration program sought to create invaluable administrative abilities, free admittance to a huge business organization, better possibilities for more significant compensation, flourishing professional openings, and experience another spot and culture. These days, these reasons did not profoundly acknowledge because it's anything but beneficial budgetary speculation, and there are preposterous assumptions regarding what it will accomplish for you. It sought after people need to work together with Administration (and understand what that involves), if the venture merits the time and cash, or people couldn't care less about money if people have a sensible possibility of a rational profession way. Moderately couples of individuals make heaps of cash with the Business Administration nowadays (Vioreanu, 2018). By the introduced circumstance, the specialists who are in the field of academe instructing business and the executive's discipline, presently, the Program Research Coordinator will evaluate the realization of the Business Administration Program Outcomes. The researchers will choose to prescribe a program intercession plan to upgrade the endeavors applied for the understudies' ongoing learning and improvement by the examination led. Principally, this investigation anticipated the advantage of the University of Cebu- 
Lapulapu, and Mandaue, explicitly in using the Business Administration Program Outcomes.

\section{FRAMEWORK}

The investigation was anchored on Program Theory, giving the right image of how change happens and how to improve execution. The Program Theory tells the best way to create, speak to, and use program hypothesis nicely and deliberately to suit a specific circumstance. The necessities appraisal to intercession plan, from usage to results assessment, from strategy definition to strategy execution and evaluation, program hypothesis is fundamental (Funnell, \& Rogers, 2011). Program hypothesis is a bunch of express or certain suspicions by partners about what activity is needed to tackle a social, instructive, or medical condition and why the difficult will react to this activity (Chen, 2012).

Program hypothesis designs partners' prescriptive suspicions and illustrative suppositions of hidden projects, regardless of whether unequivocal or specific. Expressive presumptions, called the change model, manage what causal cycles envision achieving program objectives. Prescriptive presumptions, called activity models, care about what moves must be made in a program to create attractive changes. Program hypothesis utilizes the activity model and change model to address logical factors and arranging, and usage gives that are keen on partners (Donaldson, 2012).

Upheld by the Action Model, masterminds staff, assets, settings, and backing associations arrive at an objective gathering and convey mediation administrations. The activity model comprises of the accompanying components: 1) executing an association that surveys, improve, and guarantees its abilities: A program depends on an association to assign assets, to organize exercises, and to enroll, train, and regulate implementers and other staff (Saunders, 2015).

Projects are confounded wonders, for the most part resulting from experience and expert legend. At the same time, mentioning an assessment, partners by and large need to know whether they are doing works and how they may improve their intercession. Program hypothesis can frequently give that sort of data without assembling the exploration endeavors. There is a contention that the program hypothesis doesn't reflect how the mediation creates the expected results, yet instead, partners' recognitions and convictions, right or off-base, about the systems that work between the conveyances of the intercession. The entire hypothesis is putting together concerning the agreement came to on partners' convictions and discernments (Chen, 2012).

Convictions and discernments are the roots or establishments of the person's perspective. In actuality, addressing or sifting conviction incorporates the worth the individual has. Recognition is the strategy or philosophy or perspective individuals considered it a worldview. It is the channel of any information dependent on a person's convictions (Teknomo, 2006). In a dubious and equivocal world, compelling dynamic necessitates that subjects shape And keep up accepting the rightness of their decisions, a cycle called metacognition. The expectation of future results and self-observing are viable if conviction intently coordinates social execution (Drugowitsch et al., 2014).

The above assertion is additionally strengthened by Decision Theory which, is worried about the thinking fundamental to a person's decisions. It is a decision about whether to seek after a requesting vocation. The standard reasoning is that what an individual does on some random event is controlled by an individual's convictions and wants/values. However, this isn't uncontroversial. Regardless, the choice hypothesis is a hypothesis of confidence, wants, and other critical perspectives. It is a hypothesis of decision; what makes a difference is how these different mentalities or likewise assembled inclination perspectives adhere (Steele \& Stefánsson, 2015).

When deciding, individuals commonly face vulnerability about their activities' expected results due partially to limits in their ability to speak to, assess, or consider. Regardless, they intend to settle on the ideal choices. In this hypothesis, dynamic, offering direction on how genuine people ought to speak to the vulnerability the individual is confronting, how an individual should modify feelings because of involvement, and how an individual should settle on choices when lacking full mindfulness or suppositions on pertinent possibilities (Bradley, 2017).

Vroom's Expectancy Theory is another hypothesis that underpins the investigation. Accepting that individuals spurred to perform exercises, accomplishing some objective to the degree that they expect activities would help them achieve the objective. It depends on the presumption that a person's conduct results from the decisions made concerning the elective game-plan identified with the mental occasions happening simultaneously with the conduct. An individual chooses to conduct over different practices with a desire for getting results; the one wanted for (Sims, 2002).

The logarithmic portrayal of Vroom's Expectancy hypothesis is Valence: It alludes to the worth that an individual puts on a specific result or quality of a person's inclination for the regular prizes of the product. To have a positive valence, one ought to favor accomplishing the work of not achieving it. If advancements spur a representative, at that point, he probably won't esteem offers of expanded motivations. The valence is zero if an individual inclines toward not accomplishing results to achieving it.

In the above circumstance, a representative concurs with the expanded bases. The instrumentality of the top-level result in acquiring the second level result is one of the significant contributions to valence. (for example, a degree to which the top-level prompts the second level result). Assume a 
representative longings advancement and an individual feel that better exhibition is a critical factor than accomplish the objective. In this manner, the top-level results are prevalent, familiar, and terrible, and the second level result is the advancement (Irimia and Gottschling, 2016).

\section{OBJECTIVES OF THE STUDY}

The investigation intended to assess the University of Cebu Lapu-Lapu and Mandaue Business Administration Program Outcomes for the Year 2015-2019 alumni. The consequence of this investigation would fill in as the reason for the program intercession plan to guarantee its significance to the graduates' current and future necessities. In particular, it distinguishes the respondents' profile as far as age, sex, legal status, type of revenue, Year graduated, and course major. It looks to recognize the evaluation fair and square of realization of the University of Cebu Lapu-Lapu and Mandaue Business Administration Program Outcomes additionally, as seen by the alumni respondents.

\section{IV.METHODOLOGY}

\section{A. Research Design}

The examination utilized the descriptive method for research. The researchers used a self-organized survey adjusted from the Business Administration Program Outcomes. Frequency, simple percentage, and mode were the statistical tools used to give legitimate translations of information.

\section{B. Research Environment and Respondents}

The investigation was was directed at the University of Cebu Lapu-Lapu and Mandaue grounds situated at A.C. Cortes Ave., Mandaue City. It offers a Bachelor of Science in Accountancy, Bachelor of Science in Business Administration with four majors; Management Accounting, Marketing Management, Financial Management, and Human Resource The investigation was to assess whether the alumni realized the Program Outcomes for the School Year 2015-2019; the area was suitable for the examination to give the researchers simple access and reaction from the respondents. The 673 respondents of the examination study were determined using Slovins Formula from the University of Cebu Lapu-Lapu-Lapu and Mandaue Business Administration Program alumni utilizing the snowball sampling method.

TABLE I NO. OF RESPONDENTS PER SCHOOL YEAR

\begin{tabular}{|l|c|c|}
\hline Year Graduated & f & Percentage \\
\hline $2015-2016$ & 158 & 23.48 \\
\hline $2016-2017$ & 162 & 24.07 \\
\hline $2017-2018$ & 169 & 25.11 \\
\hline $2018-2019$ & 184 & 27.34 \\
\hline Total & 673 & 100.00 \\
\hline
\end{tabular}

Table I shows the number of respondents per School Year using snowball sampling as the data-gathering technique and Slovins formula to get the sample size.

\section{Research Procedure}

\section{Data Gathering}

Letter of intent routed to the Dean of the College of Business and Accountancy for information gathering, requesting that authorization lead the review and acquires the all-out number of graduate understudies. A separate letter of request also was sent to University Registrar to obtain the total number of graduates from the school year 2015 to 2019. The surveys were managed through Google structure to the alumni respondents on snowball sampling. The information was being organized and dissected. Utilizing this boundary to decipher the reactions:

TABLE II PARAMETERS FOR INTERPRETATION

\begin{tabular}{|c|l|l|}
\hline Mode & Rating scheme: & \multicolumn{1}{|c|}{ Interpretation } \\
\hline 4 & Highly Realized & $\begin{array}{l}\text { There was proof that acted } \\
\text { pointers in all cases. }\end{array}$ \\
\hline 3 & Realized & $\begin{array}{l}\text { There was proof that markers } \\
\text { were acted as a rule. }\end{array}$ \\
\hline 2 & Less Realized & $\begin{array}{l}\text { There was proof that markers } \\
\text { acted in couple of cases. }\end{array}$ \\
\hline 1 & Not Realize & $\begin{array}{l}\text { There was no proof that the } \\
\text { pointers were performed by any } \\
\text { means. }\end{array}$ \\
\hline
\end{tabular}

The accompanying statistical tools used to encourage examination and translation:

Frequency and Simple Percentage was utilized to treat response dents' profile on age, sexual orientation, respondents' profile common status, course major, and year level.

The mode was utilized to break down information fair and square on the alumni respondents' realization in the Program outcomes.

\section{RESULTS AND DISCUSSION}

This section presents the consequences of the information accumulated. The initial segment offers the profile of the respondents. The next part shows the information on the evaluation of the acknowledgment of the Business Administration Program Outcomes for the alumni of the school year 2015-2019.

Table III shows the alumni's profile on age, sex, legal status, type of revenue year graduated, and course major. Most of the respondents matured at the scope of 20 years of age, which is equal to 47.62 percent. This information suggests that the alumni are at the youthful grown-ups stage. Upheld by the University of British Columbia (2018), expressing that the average age for understudies was 20-21 years of 
age. Concerning sexual orientation, a larger part, or $71.43 \%$ of the Business Administration program alumni, was female. Female has more tendencies to take Business Administration courses.

Concerning the joint status, the entirety of the respondents was single. Upheld by Stack Exchange (2019), expressing that if the understudy is powerful and proficient if they're available. Have involvement in exploration and composing papers, have no different obligations, in great mental and actual wellbeing, and can keep up a full course burden.

Concerning the type of revenue, $90.48 \%$ of the respondents procured through work. Upheld by Ceniza-Levine (2011), expressing the reasons why business is superior to the ambitious endeavor. The grounds that an individual can zero in on doing, rather than selling, may have more work and life balance in conventional work and pay is the most excellent resource.

Regarding course graduated, the vast majority of the respondents, or $41.43 \%$, took Management Accounting course. The Business Administration educational plan has five Program Outcomes to be specific: Meet the current interest and needs of the business in the zones of a human asset, advertising, bookkeeping, and money; Communicate and team up successfully; Utilize data innovation; Contribute to the financial turn of events and natural manageability; Adhere carefully to proficient moral norms.

TABLE III RESPONDENTS PROFILE ( $\mathrm{N}=673)$

\begin{tabular}{|c|c|c|}
\hline & Frequency & Percentage \\
\hline \multicolumn{3}{|l|}{ Age } \\
\hline 20 & 321 & 47.62 \\
\hline 21 & 224 & 33.33 \\
\hline 24 above & 128 & 19.05 \\
\hline \multicolumn{3}{|l|}{ Sex } \\
\hline Male & 193 & 28.57 \\
\hline Female & 480 & 71.43 \\
\hline \multicolumn{3}{|c|}{ Civil Status } \\
\hline \multirow[t]{2}{*}{ Single } & 480 & 71.32 \\
\hline & 193 & 28.68 \\
\hline \multicolumn{3}{|c|}{ Source of Income } \\
\hline Employed & 609 & 90.48 \\
\hline Business & 64 & 9.52 \\
\hline \multicolumn{3}{|c|}{ Course Major } \\
\hline MA & 278 & 41.31 \\
\hline FM & 154 & 22.88 \\
\hline MM & 129 & 19.17 \\
\hline HRDM & 112 & 16.64 \\
\hline
\end{tabular}

Table IV shows the consequences of the appraisal of the alumni fair and square of acknowledgment of the program outcomes of the Business Organization educational plan. There were five PO for the program, and every PO has five markers. Concerning marker that has knowledge of financial institutions and technical skills based on established economic theories, methodologies, and various analytical tools, it recorded the most minimal mode at 53.68\%. It deciphered as Realized, which implies that there was proof that the pointers were acted as a rule. It suggests that graduate respondents recognize trouble in accomplishing information on monetary foundations and specialized aptitudes dependent on setting up money related speculations, philosophies, and different systematic instruments.

It goes with the investigation of (Biggs 2003), demonstrating that proper arrangement is a case of results based instruction (OBE). Tragically, a few adaptations of OBE have pulled in analysis; utilized in some auxiliary and university frameworks in a post-present day hodgepodge of results. OBE, a valuable arrangement, is concerned uniquely with improving instructing and learning and, as such, has been effectively actualized in colleges everywhere in the world. There should be a cycle that people, as a rule, follow when working up an OBE schedule.

The word 'productive' alludes to what the student does to build significance through practical learning exercises. The 'arrangement' angle indicates what the educator does. The way into the arrangement is that the showing framework segments, particularly the instructing techniques utilized and the appraisal undertakings are adjusted to the learning exercises expected in the planned results.

Further upheld by Au, and Kwan (2009), enumerating that result based instructing and learning underscores the express affirmation of learning results which distinguish the assignments understudies are relied upon to have the option to perform in the wake of finishing the course, and to what standard. OBTL requires educating, learning, and appraisal exercises to line up with the expressed learning results.

The investigation was strengthened by Treleaven \& Voola (2008), expressing that graduate ascribes' significance is progressively perceived universally in advanced education and by industry, government, and certifying bodies. Nonetheless, coordinating the improvement of graduate clarifies, for example, basic reasoning and raw reflection, has demonstrated testing in business instruction.

This article shows the estimation of productive arrangement for incorporating graduate ascribes into a concentrated promoting course. Graduate ascribes communicated as learning results and lined up with appraisal measures. The understudies' attention to graduate credits and their worth is created and pertinence for understudies' future promoting vocations is installed into learning exercises. Significant open doors for training in creating conventional aptitudes are offered in formal and casual criticism from speakers and companions, and that a program-wide way to deal with 
creating and coordinating alumni ascribes is received. As to Able to handle diverse human capital requirements of the organization including recruitment, staffing, training, and career development implanted on the first Program outcome recorded the most noteworthy mode at $71.72 \%$ and recorded as Realized which implies the markers were acted as a rule. It infers that graduates had the option to deal with different human resources necessities of the association including recruitment, staffing, training, and career development. As per Brown (2009), A Business associate degree can enable a person to plan for a broad scope of positions as a business chief and executive. Business executives and supervisors join money with HR, advertising, and the board to support organizations. Business the board courses and business organization courses intend to assist understudies with building up a comprehension of showcasing the executives, $\mathrm{HR}$, and the job account plays in every one of these territories.

HR in Business Organization and The executive's Human asset offices and authorities are liable for a broad scope of undertakings managing faculty. Human asset authorities recruit qualified people and try to amplify the aptitudes of representatives. A large part of the crafted by human asset authorities requires a solid comprehension of monetary standards. They should contemplate an organization's spending plan and marketable strategy while employing.

Business the board courses and business organization courses can assist you with increasing comprehension of these standards and applying to a profession in HR. Advertising in Business Organization and The board every business or organization paying little mind to their size must market their item or Administration to be fruitful. Organizations that depend on the in-house promoting look to business supervisors and business managers with Partner degrees to assist them with making and meet advertising objectives.

Business, the board classes, works to outfit understudies with showcasing instruments to comprehend an organization's market and how to amplify its latent capacity. Business The executives Business supervisors, like different kinds of chiefs, center around arranging, sorting out, coordinating, and overseeing an organization or a part of an organization. Business administrators help put together business issues to amplify their proficiency. A solid handle of business and account standards help business directors produce and audit marketable strategies and reports for their managers. Fruitful business directors and heads must join money with HR, advertising, and executives to help organizations succeed and develop.

Business the board courses and business organization courses help people better comprehend an organization's market, survey their recruiting rehearses, and deal with their business. Business the board preparing might be only the edge you have to break into the energizing field of business the executives and organization.
The above assertion was additionally upheld by Audra (2019), itemizing That HR supervisory group recommends to the supervisory crew how to oversee individuals as business assets deliberately. Selecting and recruiting workers with explicit ranges of abilities to meet the organization's current and future objectives in planning representative advantages and proposing worker preparing and advancement systems. Along these lines, HR experts are advisors, not laborers in detached business work; they prompt chiefs on numerous issues identified with representatives and how they help the association accomplishes its objectives.

The investigation of Mahea (2014), specifying that the function of showcasing in associations is too critical ever to be disregarded. Enormous and little associations are going after a similar market and the most imaginative and proactive have arisen victors. The present worldwide economy has understood the significance of small associations and progressively giving them genuinely necessary help to support their development. Subsequently, an organization's endurance relies upon its astute advertising endeavors coupled with money-related operational capacities among different capacities inside its structure.

Online media roads have been meddled by associations looking to catch the crowd with their item and administration contributions. The majority of them have, in reality, achieved many accomplishments, and clients are more educated than they were a couple of years back.

Showcasing assumes a significant part in building up connections among clients and the associations offering to the market. It gives us the certainty to attempt another item in the market rather than circumstances where the objects enter the market without exposure. The advertising capacity essential in each association independent of whether the association is benefit or non-benefit focused. Showcasing shapes the association's picture, how individuals partner the association's items or administrations and undoubtedly give individuals certainty about their items or administrations. When it goes to the benefit drove associations, promoting is liable for the expansion in income and augmentation increment in the association's productivity.

What's more, the capacity additionally helps to develop the client/customer base for the association. The promoting capacity is also entrusted with the marking the association, support in exposure exercises, publicizing,, and client collaboration through criticism assortment. Item dispatch begins with advertising, and ends with promoting. Office builds up the shoppers' necessities, and after presenting the item, the office looks to recognize and met the client's requirements. Associations contend to be at the highest point of the clients' minds and simultaneously attempt to secure their piece of the overall industry. Showcasing is at the focal point of making client dedication and client maintenance. The capacity does advancements, crusades now and then. This capacity has been demonstrated as a 
significant activity in additionally pulling in more clients. The Association's prosperity is not controlled by the judicious use of assets to the different venture arrangement. Relationship also sets up with the clients, which is a component of showcasing. Bookkeeping is the best approach to keep track of who's winning an organization's exercises. However, an account rejuvenates a business. The report goes through all aspects of a company's activities.
Hardly any choices are ever constructed without contribution from the individuals in monetary Administration. The account is basic in pretty much every business choice, from arranging and planning and income the executives to the capital structure and how you control dangers and costs (Woodruff, 2019).

\section{TABLE IV LEVEL OF ASSESSMENT ON MEETING THE CURRENT DEMAND AND NEEDS OF THE INDUSTRY IN THE AREAS OF HUMAN RESOURCE, MARKETING, ACCOUNTING, AND FINANCE AS PERCEIVED BY THE RESPONDENTS}

\begin{tabular}{|l|c|c|c|c|}
\hline & Mode & Interpretation & (\%) & Rank \\
\hline $\begin{array}{l}\text { Able to handle diverse human capital requirements of } \\
\text { the organization, including recruitment, staffing, } \\
\text { training, and career development }\end{array}$ & 3 & Realized & 71.72 & 1 \\
\hline $\begin{array}{l}\text { Able to perform technical skills in marketing, market } \\
\text { research, advertising, and public relations }\end{array}$ & 3 & Realized & 65.94 & 2 \\
\hline $\begin{array}{l}\text { Promotes and outlook based on ethics, market integrity, } \\
\text { regulations, good governance, and competitive global } \\
\text { perspective necessary for decision making. }\end{array}$ & 3 & Realized & 65.94 & 2 \\
\hline $\begin{array}{l}\text { Able to provide and partner management in decision- } \\
\text { making, devise planning and performance management } \\
\text { systems and provide financial reporting and control } \\
\text { expertise. }\end{array}$ & 3 & Realized & 55.41 & 3 \\
\hline $\begin{array}{l}\text { Has knowledge of financial institutions and technical } \\
\text { skills based on established economic theories, } \\
\text { methodologies, and various analytical tools. }\end{array}$ & 3 & Realized & 53.68 & 4 \\
\hline Overall Mode & 3 & Realized & & \\
\hline
\end{tabular}

Table V shows the aftereffects of evaluating the alumni fair and square of acknowledgment of the $\mathrm{PO}$ of Business Administration educational program. As to able to hold meetings with necessary and meaningful; it recorded the most minimal mode at $53.70 \%$ and recorded as Realized, which implies that there was proof that the markers were acted by and large. It suggests that graduate respondents experience trouble in taking care of gatherings with an essential and significant plan. The explanation might be that the open door isn't there for them to dominate in the field.

Derrick (2019) indicated that a very much organized gathering plan is an essential instrument for guaranteeing that gatherings accomplish wanted outcomes inside the time designated. A strategy assumes a critical part in making gathering profitable. It ensures that relevant data concerning the issues to be examined is passed to the members ahead of time. Therefore, it will give members an excellent chance to do their examination and interviews since the plan contains a rundown of the themes or issues to be handled.

All the individuals welcomed for the gathering realize what's in store. A list is huge in keeping the members zeroed in on the current theme. It contains a rundown of gathering's objectives, just as the significant issues essential in keeping the conversation fixated and can be accomplished by educating the members regarding the needs or giving a thought to all issues and activities that influence every member.
Upheld by Heathfield (2019), expressing that the gathering chief is the representative who is liable for arranging, coordinating, dealing with the insights concerning, and welcoming the members to a gathering. They are the representative who is accountable for and responsible for the advancement of the real community.

They make a move previously, during, and after the conference to virtually guarantee that the gathering arrives at its objectives. Meeting pioneer is critical in creating communities and groups fruitful. The worker who fills in as the gathering chief is significant. In specific gatherings, the pioneer in the office head, the group chief, or the individual delegated by senior Administration to lead an activity. Workers chose influential position given their apparent aptitudes as a supervisor or pioneer. On different occasions, a worker may arise as the pioneer naturally. These pioneers are representatives that foreign workers turn upward to and regard. On other events, a group may choose to pivot the influential position among all individuals.

To set the model and lead from the top, the pointer recorded the most noteworthy mode at $70.98 \%$ and deciphered as Realized. It infers that graduate respondents do acquire the duty of driving individuals and driving an administration on top. As per Kukreja (2018), Administration is the capacity of an individual or gathering of people to lead, guide, or impact other groups of individuals or an association. The initiative involves; having an unmistakable vision, the capacity to impart the idea to colleagues, the ability to put 
together powerfully and effectively, rousing subordinates towards satisfaction of association's objectives and adjusting the irreconcilable situation, everything being equal, and partners. Administration includes all circles of life; family, political, executives, or monetary. Authority requires aptitudes even though it tends to be educated, improve through tutoring and instructing; however, it is, to a greater extent, expertise. The center ability of Administration is impacting. Indeed John C. Maxwell characterizes Administration as impact; how well you can move your subordinate or circumstance makes you a pioneer: a pioneer is somebody who controls or coordinates others.

Along these lines, it is basic to know and comprehend a decent pioneer's significance and characteristics. Significance of Good Pioneer: Giving direction: Direction includes preparing, teaching colleagues along with the vision or objective of the association, and guarantees no deviation from the vision or objective even though it will warrant embracing remedial measures. It also involves the leader's capacity to give counsel that will permit colleagues to develop a lot. Empowering inventiveness: Great pioneers relinquish their self-image and give their subordinates space to communicate to support novel thoughts.

These advancements can trigger an association to move into the new thousand years. For example, a pioneer may choose to avoid a specific undertaking for colleagues to finish, just supporting their innovativeness. Since inventiveness lies in each man yet the component to release it could be unique. The pioneer is in a shaft position to release the imagination that every individual from the group has, regardless of whether they are unconscious. Inspiration: Inspiration is indispensable to the accomplishment of an association. A decent pioneer guarantees colleagues' energy is high to play out the employment to their absolute best.

An effective pioneer propels colleagues by building trust and trusts in them so that; they adopt a positive strategy to the work and the association on the loose. Inspiration is additionally accomplished by establishing a hitch free climate by building trust among colleagues so to improve fellowship among the colleagues comparable to organization destinations, as opposed to zeroing in on singular objectives. Motivators likewise can be a medium to rouse colleagues. Correspondence: co-appointment of work successfully and proficiently requires brilliant correspondence between group pioneer and colleagues. Correspondence includes trade of thoughts, data and messages between individuals at a specific spot and time through talking, composing or signals. Compelling correspondence is the bed rock to successful authority and its substance is to make understanding. Rollo May, American therapist remarks, "Correspondence prompts network, that is, to getting, closeness and shared esteeming". A decent pioneer will have the option to make comprehension of the vision, qualities and bearing of the association to the colleagues or people engaged with the business in clear terms. Cultivate great qualities: Show of good qualities is indispensable to the accomplishment of an association. A decent pioneer will attempt to encourage great qualities among colleagues by representing it. For example, a pioneer that shows lowliness, respectability and generosity will fill in as model for the colleagues to assimilate such character subsequently upgrading the profitability of the association. Compromise: A beneficial pioneer oversees clashes that remain as danger to solidarity of colleagues, profitability and inspiration. Struggle is best managed in the crude stage in this manner it is significant for a pioneer to perceive indications of contention ahead of schedule before it heighten.

Anyway it is relevant to comprehend that there are positive clashes that may emerge that require diverse methodology. To undaunted clash a pioneer would need to assess the circumstance, build up a typical comprehension of the issue, receive arrangements and by understanding select an answer. Devices compelling pioneers draw in to oversee clashes incorporates, Staying away from; not everything clashes can be dodged, Obliging; in light of a legitimate concern for the group, a colleague may need to venture down, Bargain; one of the gatherings engaged with strife may need to venture down, Synergistic; by working intimately with the group a group chief can cultivate coactivity among colleagues and Driving; practice authority if regard vital. Characteristics of Good Pioneer: Impact: The effect a pioneer has on its colleagues decides the adventure of colleagues. Relational abilities: Great pioneers impart plainly both verbally and in composed structure in a way the group will comprehend the destinations chief must have the option to listen effectively and comprehend from the point of view of the colleagues, listening likewise incorporates noticing the non-verbal communication and other natural signs.

Viable listening enables the pioneer to give a more complete comprehension of the data. Assignment: A decent pioneer realizes the duties to share and who to impart it to so to improve profitability. Certainty: A decent pioneer must be sure and must have the option to ingrain certainty into colleagues. A sure pioneer doesn't falter over his choices. Association: A decent pioneer must have outstanding hierarchical abilities to organize organization objectives and destinations in such a way that will upgrade colleagues' efficiency. It additionally includes setting up boundaries those aide colleagues towards achieving organization points and targets. Exchange: Arrangement is the way toward building up a commonly sufficient interest in the irreconcilable circumstance. An effective pioneer must have the option to arrange aloofness in colleagues' interests and build up a typical interest. Unprejudiced: A pioneer must be fair-minded in dealings with colleagues. Trustworthiness: It is basic for a pioneer to have respectability. A decent pioneer must consistently show genuineness to pick up colleagues' trust (Kukreja, 2018).

The current examinations show that regularly organizations need more pioneers inside worldwide skills and that 
opposition for such assets is considerably more concentrated. Then again, it has been contended that this isn't yet the situation, and subsequently, organizations don't have the foggiest idea what skills they should zero in on. Additionally, it has been contended that the improvement of worldwide capabilities isn't a well advanced cycle inside organizations (Suutari, 2002).

It was additionally upheld by Randall \& Wallace (1996), expressing that to offer a down to earth, coordinated model of viable administration conduct, we stress consensus and effortlessness. Five recommendations underlie our Administration Connection Model: (1) pioneers, task (plan), and supporters contribute intuitively to task achievement the primary focal point of any work try, (2) two comprehensively imagined measurements, physical and mental, depict the workplace, (3) viable and productive achievement of existing errands result from commitments adding to address precisely add up to requests along with these measurements, (4) successful initiative style conduct gives the connection to finish the specific match among assignment, adherents, and authority style, and (5) a pioneer effective in these value-based parts of undertaking authority liberates himself/herself for the more extensive duties of building vision. We examine how our connecting model joins a few notable administration models and permits a combination of their remedies.

TABLE V LEVEL OF ASSESSMENT ON COMMUNICATING AND COLLABORATING EFFECTIVELY; AS PERCEIVED BY THE RESPONDENTS

\begin{tabular}{|l|c|c|c|c|}
\hline & Mode & Interpretation & (\%) & Rank \\
\hline $\begin{array}{l}\text { Set the example } \\
\text { and lead from the } \\
\text { top }\end{array}$ & 3 & Realized & 70.98 & 1 \\
\hline $\begin{array}{l}\text { Encourage social } \\
\text { interaction }\end{array}$ & 3 & Realized & 64.21 & 2 \\
\hline $\begin{array}{l}\text { Able to provide } \\
\text { clarity of roles } \\
\text { and functions } \\
\text { among } \\
\text { subordinates }\end{array}$ & 3 & Realized & 64.21 & 2 \\
\hline $\begin{array}{l}\text { Able to make } \\
\text { oneself be } \\
\text { understood }\end{array}$ & 4 & $\begin{array}{c}\text { Highly } \\
\text { Realized }\end{array}$ & 53.70 & 3 \\
\hline $\begin{array}{l}\text { Able to hold } \\
\text { meetings with } \\
\text { necessary and } \\
\text { meaningful } \\
\text { agenda }\end{array}$ & 3 & Realized & 53.70 & 3 \\
\hline Overall Mode & 3 & Realized & & \\
\hline
\end{tabular}

Table VI shows the aftereffects of the appraisal of the alumni fair and square of acknowledgment of the PO of Business Administration educational program. As to able to adopt a Management Information System and audit Information system; it recorded the most reduced mode at $48.19 \%$ and deciphered as Realized. It infers that graduates don't have a decent establishment of learning with regards to innovation as such on Management Information System and
Audit data framework. Upheld by Weber and Brusilovsky (2001), specifying the issues of creating flexible, versatile, and wise learning frameworks that Ube utilized regarding useful Web-based instruction contends that flexibility is a significant component of fruitful Web-based training frameworks. It presents ELM-ART, a savvy, intelligent instructive framework to help to pick up programming. ELM-ART gives all learning material online as a versatile, intuitive course reading. Utilizing a mix of an overlay model and a roundabout understudy model, ELM-ART offers versatile route uphold, course sequencing, the individualized conclusion of understudy arrangements, and model-based critical thinking support.

Chih-Ming et al. (2006), Giving bits of knowledge that educational program sequencing is a significant examination issue for Web-based guidance frameworks is that no fixed learning pathway will fit all students. Subsequently, numerous analysts zeroed in on creating elearning frameworks with customized learning components to help online Web-based learning and adaptively give learning pathways. Notwithstanding, most customized frameworks think about student inclinations, interests, and perusing conduct in giving customized educational program sequencing administrations. These frameworks generally disregard to consider whether student capacity and the trouble level of the prescribed courseware were coordinated to one another or not.

For the most part, unseemly courseware prompts student intellectual over-burden or confusion during learning, in this manner decreasing learning impact. Moreover, idea coherence of learning pathways should be thought of while actualizing customized educational plan sequencing. Smoother learning pathways increment learning impact, staying away from pointlessly troublesome ideas. The investigation introduced a model of customized Web-based guidance framework (PWIS) in light of the proposed altered Item Response Theory (IRT). To perform customized educational program sequencing all the while considering courseware trouble level, student's capacity, and the idea progression of learning pathways during learning. In the proposed changed IRT, the data work is reconsidering the idea progression of learning pathway just as considering the trouble level of courseware and individual student capacity. Test results demonstrate that applying the proposed adjusted IRT for Web-based learning can develop appropriate learning pathways for students for customized education and learn more viably.

As indicated by the investigation of Scutter et al. (2010), Podcasting is usually utilized recreationally and is currently used progressively in schooling. The innovation for Podcasting is promptly accessible, simple to use, and economical, making it an attractive choice for giving extra adaptable learning assets to understudies. Wunderstudies and the suggestions for learning utilize webcasts. Understudies commonly utilized webcasts to audit address content, mainly when they experienced getting addresses or 
new wording. Understudies naturally tuned in to the chronicles while seeing the talk PowerPoint introductions on a home PC. The examination shows that scholastics need to think about the presentation of instructional techniques; for example, webcast addresses inside the more extensive set of instructional objectives.

Further fortified by Fernandez et al. (2009), (1) podcasting is a useful asset as a supplement to the conventional assets on a course, yet not a substitute for them; (2) the attributes of podcasting increment the impression of perpetual contact among understudies and instructors, expanding understudies' inspiration; (3) the utilization of Podcasting considers an assorted scope of understudy aptitudes and learning strategies.

The above assertions were additionally upheld likewise by France \& Wheeler (2007), which recommended that the utilization of podcasting task input (PAF) gave upgraded occasions to convey both conventional and individualized criticism to understudies and an improved understudy learning experience.

More subtle 'results' incorporated the significance of the tone of oral conveyance of the webcast and the less shallow nature with which understudies treated digital broadcast input The ability to adapt and utilize social media business platforms recorded the mode at 54.69\%.

It deciphered as Realized. It infers that not a many alumni respondents are ready to embrace and use online media business stages. As per Nielsen \& Schrøder (2014), the developing utilization of online media like Facebook and Twitter is currently changing how news is created, scattered, and discussed. Be that as it may, up until this point, we have just a fundamental comprehension of (1) how significant web-based media are as wellsprings of information comparative with other media, (2) the degree to which individuals use them to discover news, (3) the number of utilization them to participate in more participatory types of information use, and (4) regardless of whether these improvements are comparative inside nations within any case practically identical degrees of a mechanical turn of events. We show that TV stays both the most broadly utilized and most significant wellspring of information in every one of these nations. Those even print papers are generally used and seen as more significant wellsprings of information than online media.

It distinguishes a bunch of similitudes as far as the developing significance of online media as a component of individuals' cross-media news propensities, yet also significant nation to-nation contrasts, specifically as far as how broad the more dynamic and participatory types of media use are. Shockingly, these distinctions don't compare to contrasts in levels of web use, proposing that more than simple accessibility shapes the function of online media as parts of individuals' news propensities.
TABLE VI LEVEL OF ASSESSMENT ON UTILIZING INFORMATION TECHNOLOGY AS PERCEIVED BY THE RESPONDENTS

\begin{tabular}{|l|c|c|c|c|}
\hline & Mode & Interpretation & (\%) & Rank \\
\hline $\begin{array}{l}\text { Utilize technology } \\
\text { in the business } \\
\text { decision-making } \\
\text { process }\end{array}$ & 3 & Realized & 59.45 & 1 \\
\hline $\begin{array}{l}\text { Lestablish their } \\
\text { own E-commerce } \\
\text { business }\end{array}$ & 3 & Realized & 59.45 & 1 \\
\hline $\begin{array}{l}\text { Able to adapt and } \\
\text { utilize social media } \\
\text { business platforms }\end{array}$ & 3 & Realized & 54.69 & 2 \\
\hline $\begin{array}{l}\text { Able to identify and } \\
\text { use } \\
\text { telecommunications } \\
\text { equipment } \\
\text { efficiently }\end{array}$ & 4 & $\begin{array}{c}\text { Highly } \\
\text { Realized }\end{array}$ & 49.93 & 3 \\
\hline $\begin{array}{l}\text { Able to adopt a } \\
\text { Management } \\
\text { Information System } \\
\text { and audit } \\
\text { Information system }\end{array}$ & 4 & $\begin{array}{c}\text { Highly } \\
\text { Realized }\end{array}$ & 48.19 & 4 \\
\hline Overall Mode & 3 & Realized & & \\
\hline
\end{tabular}

Table VII shows the after effects of the appraisal of the alumni fair and square of acknowledgment of the PO of Business Administration educational program. As to conduct in-service community livelihood training programs, it recorded the most minimal mode at $43.15 \%$. It deciphered as Realized. It infers that graduates don't have any inclusion on network work preparing programs.

In the investigation of Yi-ping et al. (2014), work systems indicate the reach and blend of families' exercises and decisions. Some examination has zeroed in on the expected effects of supportable vocation, and a couple of studies have started thinking about the efficacy of business systems. Given the inclination height and resettlement venture, mountain settlements are grouped into four sorts: the highmountain settlement, the semi-mountain settlement, the waterway valley settlement, and the resettlement zone. Utilizing semi-organized meetings, we have characterized the homestead and non-ranch occupation systems as needy factors. At the same time, the common, human, physical, budgetary, and social capitals are considered as autonomous factors to show the connection between business techniques and vocation capitals. In terms of various settlements, we gauge the homestead and non-ranch business systems' affectability to job capitals. The outcomes demonstrate that regular and human means showed a positive connection with the ranch vocation methodology, even though the impact changes with the four sorts of settlements. Money related and social capitals are the impetus for driving nonranch exercises. Our discoveries propose that no size fits all answers for the job methodology issues. Just vocation capitals will be useful in the long haul on the off chance that they are supplemented by comparative approaches that improve capital limit just as increment admittance to capitals. 
Fortified by Haan (2000), expressing that occupation is spoken to all dynamic collaborations among entertainers and five fundamental capitals. These indispensable capitals are inserted in a social, monetary, political, and environmental structure. Cooperation among entertainers and structure happens using through access and organization and results in preparing capitals to manufacture work. Job is reasonable if it can do sufficiently fulfilling self defined needs and make sure about individuals against stuns and focuses on putting on capitals by auxiliary components. Occupation techniques create in fields of clashing or cooperating entertainers. Since job procedures are numerous, people may have various vested parties, and like this social incorporation and prohibition are rarely inflexible. Globalization is deciphered as confinement, which means a nearby relationship among homogenization and variety or between the worldwide and the neighborhood. Variety isn't restricted to socio cultural areas yet saw in monetary and political spaces as well.

The indicator is to conduct financial, business training and development seminars on the different clusters in the society; it recorded a mode of $69.92 \%$ and deciphered as Realized. It infers that many of the respondents had the opportunity to do training and an improvement workshop on the various bunches in the general public.

As expressed by Hart (2016), training is a significant segment of maintaining a successful business. With the end goal for representatives to realize how to work innovation, hold fast to measures, and extend their insight on items or administrations, preparing is the essential driver in building these utilitarian abilities for associates to prevail in their job. By giving proper learning openings, you put resources into your business's achievement and show you are focused on building up your staff. Numerous businesses believe that offering preparing or improvement openings will be excessively costly.

They frequently choose to disregard the authoritative and work environment inadequacies that can regularly be fixed through preparing arrangements. In any case, they wind up going through more cash through turnover costs, diminished profitability, and low proficiency rates just because they will not see preparing's degree of profitability potential. Despite the basic reasons business pioneers like to use as expected disadvantages (time away from work, budgetary limitations, and so on), preparing and improvement gives both the organization overall and the individual representative with benefits that make the expense and time beneficial speculation. Here are only a couple of ways that actualizing preparing and advancement for your association can affect your main concern: Closing the Gaps; most representatives have open doors for development regarding their range of abilities or competency level. Executing a particular preparing program or focused on learning arrangement permits the representative the opportunity to fortify those abilities and help close the information hole. Preparing can carry every representative to a more elevated level of efficiency, pushing their aptitudes and information to rise to the ground with each other.

Decreases any frail connections and lacks inside the organization, particularly when you need to depend on others to finish fundamental work errands intensely. Giving essential preparation makes a proficient general staff with representatives who can take over for each other varying, fill in the hole, chip away at groups or work autonomously without steady assistance and oversight.

Ceaseless Business Improvement is when a representative, who gets the vital preparation, is better ready to play out her occupation. It constructs the worker's certainty since the person has a more grounded comprehension of the business they are working in obligations should have been effective. This certainty winds up driving optional execution, which is the readiness to accomplish more since they need to, not because they need to.

When given the devices to dominate, performing more diligently and quicker, we likewise attempt and consider approaches to improve. Consistent preparation can keep your workers on the bleeding edge of the industry, innovation, and operational turns of events. Representatives; who are skillful and enabled to help change business as usual help your organization hold a situation as a pioneer and solid contender. Consistency; structured preparing and improvement programs guarantee representatives have a steady encounter regarding finding out about organization desires, administrations, items, cycles, arrangements, and systems.

Building up reliable business and working standards just fortifies your business' odds for long haul achievement. Representative Engagement; Employees who routinely have nearby admittance to preparing and improvement openings have an expanded favorable position over workers who are left to look for preparing openings outside of their business. The interest in preparing that an organization makes shows the representatives they are esteemed and have faith in their prosperity inside the association.

Offered preparation can make a strong and exceptionally drew in the working environment for representatives. Exploration shows that workers who feel acknowledged and tested through preparing openings feel more fulfilled in their positions. By establishing a climate where workers feel acknowledged and sustained, businesses decrease the danger of high turnover and regularly observe more elevated individual and group profitability levels. 
TABLE VII LEVEL OF ASSESSMENT ON CONTRIBUTION TO SOCIO-ECONOMIC DEVELOPMENT AND ENVIRONMENTAL SUSTAINABILITY; AS PERCEIVED BY THE RESPONDENTS

\begin{tabular}{|l|c|c|c|c|}
\hline & Mode & Interpretation & (\%) & Rank \\
\hline $\begin{array}{l}\text { Conduct financial, business training, and } \\
\text { development seminars on the different } \\
\text { clusters in the society. }\end{array}$ & 3 & Realized & 69.92 & 1 \\
\hline $\begin{array}{l}\text { Self-involvement in different } \\
\text { professional organizations that promotes } \\
\text { social responsibility. }\end{array}$ & 3 & Realized & 58.44 & 2 \\
\hline Offer employment opportunities. & 4 & Highly Realized & 49.92 & 3 \\
\hline Lend capital to SME’s. & 3 & Realized & 48.92 & 3 \\
\hline $\begin{array}{l}\text { Conduct in-service community } \\
\text { livelihood training programs. }\end{array}$ & 3 & Realized & 43.15 & 4 \\
\hline Overall Mode & 3 & Realized & & \\
\hline
\end{tabular}

Table VIII shows the consequences of evaluating the alumni fair and square of acknowledgment of the PO of Business Administration educational program. As to Comply permits and licenses in conducting a business, it recorded the most noteworthy mode at $65.94 \%$. It deciphered as Highly Realized.

It suggests that graduates commonly slanted in complying with the arrangement of rules and principles before directing the business.

Graduates incredibly show a decent realizing regarding the underlying industry necessity, which adjusts to the law. Gunningham et al. (2004), expressing the idea of the corporate "social permit," oversees the degree to which an enterprise is obliged to meet cultural desires and maintain a strategic distance.

From exercises that social orders (or persuasive components inside them) regard inadmissible, regardless of whether those desires are exemplified in law.

It shows the attempt social permit is significant, the conditions in which it might urge organizations to go "past consistence" with the guideline.

Generally, this exploration exhibits that corporate ecological conduct can't be clarified simply as far as instrumental dangers and good commitments to conform to the law and that the expanding occurrence of "past consistence" corporate conduct can be better clarified regarding the exchange between prevailing burdens and monetary imperatives.

This was fortified additionally by Wade et al. (2010), enumerating that informal communities are more significant for new business activity in arising than in created economies.

Moreover, in arising economies, the connection between associational movement and new business action is more grounded for nations with higher administrative and standardizing institutional weights, while these arbitrator impacts are missing in created economies.

Licenses and permits are required, and before you can legitimately start to work your business, you have to have

every one of its licenses and allows set up. Also, if your business has representatives or sells available merchandise or administrations, you have to enroll with the burdening

specialists. Necessities change by industry and rely upon how and where you lead the business. Permits to operate allows, and charge enlistments are given and directed by all degrees of government, bureaucratic, state, and nearby, which incorporates province and city governments.

By and large, you may require licenses on each legislative level. Besides, there are different organizations and divisions engaged with the permitting cycle. Not being agreeable with all licenses, allows, and charge enrollments could leave you unprotected lawfully, may prompt costly punishments, and can risk your business.

With pressure against raising conventional duties, governments are consistently keeping watch for elective income streams, which implies ever expanded watchfulness for a permit to operate dodgers (Polatsek, 2019).

The gauge of legitimately required time for firms to finish a specific lawful and administrative cycle gave by the Doing Business study doesn't sum up even unobtrusively well the experience of firms as detailed by the Enterprise Surveys.

At the point when exacting by law guideline and high paces of tax collection meet powerless administrative capacities for execution and implementation, we contend that specialists and policymakers should quit considering guidelines making "rules" to be followed, yet rather as making a space in which "bargains" of different sorts are conceivable (Hallward et al., 2015). 
TABLE VIII LEVEL OF ASSESSMENT TO ADHERE STRICTLY TO PROFESSIONAL, ETHICAL STANDARDS; AS PERCEIVED BY THE RESPONDENTS

\begin{tabular}{|l|c|c|c|c|}
\hline & Mode & Interpretation & (\%) & Rank \\
\hline $\begin{array}{l}\text { Complies with permits } \\
\text { and licenses in } \\
\text { conducting a business. }\end{array}$ & 4 & $\begin{array}{c}\text { Highly } \\
\text { Realized }\end{array}$ & 65.94 & 1 \\
\hline $\begin{array}{l}\text { Perform business } \\
\text { practices that conform } \\
\text { to labor laws. }\end{array}$ & 3 & Realized & 56.43 & 2 \\
\hline $\begin{array}{l}\text { Attends training and } \\
\text { seminars that promote } \\
\text { and develop ethical } \\
\text { standard }\end{array}$ & 4 & $\begin{array}{c}\text { Highly } \\
\text { Realized }\end{array}$ & 51.69 & 2 \\
\hline $\begin{array}{l}\text { Making sure that the } \\
\text { company's or } \\
\text { organization's code of } \\
\text { ethical standards is } \\
\text { observed and in the } \\
\text { form of writing. }\end{array}$ & 3 & Realized & 48.67 & 2 \\
\hline $\begin{array}{l}\text { Being a model of } \\
\text { ethical behavior in the } \\
\text { organization }\end{array}$ & 3 & Realized & 42.23 & 2 \\
\hline Overall Mode & 3 & Realized & & \\
\hline
\end{tabular}

\section{CONCLUSION}

Program results are rules that measure the adequacy of the current educational plan, which speaks to wide articulations and higher perspective that depicts expansive parts of conduct and incorporate various learning encounters. The study concluded that to ensure the realization of the Program Outcomes, the College of Business and Accountancy should give a respectable stage, approaches, and methods.

Program Outcomes were not perceived because graduates won't prefer to appreciate business venture and network administration augmentation considering financial and time obligation. With this circumstance, an understudy having research-based headings and a practicality study is a point of realization that will propel a respectable social impact is esteemed vital.

The findings revealed that more community services spreading business and management advancement ought to be adapted to guarantee supportability in community livelihood programs is a thing to be considered to strengthen community extensions highlighting the department's stronghold discipline. Additionally, the Progression of mechanical ways to deal with instructing and learning order as the best answer to ride on with the pattern on Ecommerce and other innovative apparatuses in business for the alumni is highly recognized.

Proficiency in education in the new worldwide situation touches off a need to be educated in technology to completely contend, planned, and makes approaches to be powerful and proficient on settling business.

\section{REFERENCES}

[1] Au, O and R. Kwan, "Experience in Outcome-Based Teaching and Learning," Hybrid Learning and Education Lecture Notes in Computer Science, 133-139. Retrieved from https://bit.ly/2Kc5OY1, 2009.

[2] R. Bradley, "Decision Theory with a Human Face," Cambridge University Press, Retrieved from https://bit.ly/2CTsPs3, 2017.
[3] J. Biggs, "Teaching for Quality Learning at University - What the Student Does 2nd Edition SRHE," Open University Press, Buckingham. Retrieved from https://bit.ly/33O3Bau,2003.

[4] S. Brown, "Interested in human resources, finance, marketing, and management? Combine them all in a business administration and management associate degree," Retrieved from https://bit.ly/2n3ZbLW, 2009.

[5] H.T. Chen, "Theory-driven evaluation: Conceptual framework, application, and advancement," Sage Publications Inc. Retrieved from https://bit.ly/2IcO0sP, 2012.

[6] J. Derrick, "Importance of Having an Agenda for Meetings," Retrieved from https://bit.ly/2n9oJae, 2019.

[7] S. Donaldson, "Strategies and Applications: Program TheoryDriven Evaluation of Science,” Hove, East Sussex BN3 2FA, New York: Routledge. Retrieved from https://bit.ly/2OS0uqR

[8] V. Fernandez, P. Simo and J.M. Sallan, "Podcasting: A new technological tool to facilitate good practice in higher education," "Computers \& Education, Vol.53, No.2, 2009, pp.385- 392, ISSN 0360-1315, Retrieved from https://bit.ly/2IFL5LM, 2009.

[9] D. France and A. Wheeler, Reflections on using Podcasting for student feedback. The planet, Vol.18, No.1, pp.9-11. https://bit.ly/37aoDnu, 2007.

[10] C. Funnell and P.J. Rogers, "Purposeful Program Theory: Effective Use of Theories of Change and Logic Models. John Wiley \& Sons, Retrieved from https://bit.ly/2XUN80W,2011.

[11] N. Gunningham, R.A. Kagan and D.Thornton, Social License and Environmental Protection: Why Businesses Go Beyond Compliance. Law and Social Inquiry, Vol.29, No.2, pp.307-342. Retrieved from https://bit.ly/37SRX16, 2004.

[12] L.J.D. Haan, "Globalization, Localization, and Sustainable Livelihood,” Sociologia Ruralis, Vol.40, No.3, pp. 339-365. https://bit.ly/3oEM7XC, 2000.

[13] Hallward-Driemeier, Mary, and Lant Pritchett, "How Business Is Done in the Developing World: Deals versus Rules." Journal of Economic Perspectives, Vol.29, No. 3, pp.121-40.Retrieved from https://bit.ly/3oKNg08, 2015.

[14] L.D. Hammond, L. Flook, C.C. Harvey, B. Barron and D. Osher, "Implications for educational practice of the science of learning and development," Applied Developmental Science, Vol.24, No.2, pp.97-140, Retrieved from https://bit.ly/3pQsZr2, 2020.

[15] J. Hart, "The Importance of Training \& Development for a Successful Business. Retrieved from https://bit.ly/2m5og9d, 2016.

[16] S.M. Heath field, Roles and Responsibilities of a Meeting Leader. Retrieved from https://bit.ly/2nBU1qy, 2019.

[17] R. Irimia and M. Gottschling, "Taxonomic revision of Rochefortia Sw. (Ehretiaceae, Boraginales),”Biodiversity Data Journal 4 E7720, Retrieved from: https://bit.ly/2Ux6YAU, 2016.

[18] S. Kukreja, "Importance and Qualities of a Good Leader," Retrieved from https://bit.ly/2n4TaP6, 2018.

[19] M. Lewis, S. Kroeger and M. Zender, "Defining Program-Based Student Learning Outcomes (SLOs) and Translating Them Into a Curricular Structure. Chelsea House Publishing,” Retrieved from https://bit.ly/2CZZNan, 2009.

[20] T. Mahea, "The Role of Marketing in Organizations - By Timothy Mahea," Retrieved from https://bit.ly/2m2Ib8L.2014.

[21] R.K...Nielsen and K.C. Schrøder, "The Relative Importance of Social Media for Accessing, Finding, and Engaging with News. Digital Journalism, Vol.2, No.4, pp.472-489. Retrieved fromhttps://bit.ly/3a3WPTy, 2014

[22] D. Polatsek, "Why You Need a Business License," Retrieved from https://bit.ly/2ooemjv, 2019.

[23] G. Randall,Sleeth and R.Wallace Johnston, "The Effective Leader as a link between task and People," SAM. Advanced Management Journal Vol.61, No. 2, Spring 1996), pp. 16-21. Retrieved from https://bit.ly/3gFFHVJ, 1996.

[24] R. Saunders, "Implementation of Monitoring and Process Evaluation”. United States of America: SAGE Publications, Inc. Retrieved from https://bit.ly/2ORuCTg, 2015.

[25] R. Sims, "Managing Organizational Behavior," 88 Post Road West, CT 06881, United States of America. Greenwood Publishing Group, Inc. Retrieved from https://bit.ly/2Ho5S3A,2002.

[26] K.Steele and H.O.Stefánsson, "Decision Theory," Cambridge University Press. Retrieved from https://stanford.io/3qQuUww, 2015. 
Kingie G. Micabalo and Ryan D. Montilla

[27] V. Suutari, "Global leader development: an emerging research agenda," Career Development International, Vol. 7 No. 4, pp. 218233. Retrieved from https://bit.ly/2JMDtrB, 2002.

[28] S. Scutter, I. Stupans, T.Sawyer and S. King, "How do students use podcasts to support learning?. Australasian Journal of Educational Technology, [S.l.], v. 26, n. 2, apr. 2010. ISSN 1449-5554. Retrieved from https://bit.ly/3gCWZCR, 2010.

[29] L. Treleaven and R. Voola, "Integrating the Development of Graduate Attributes Through Constructive Alignment," Journal of Marketing Education, Vol.30, No.2, pp. 160-173. Retrieved from https://bit.ly/2WkujVX, 2008.

[30] D. Vioreanu, "7 Very Good Reasons to Do an MBA Degree," Retrieved from https://bit.ly/2YQCfhy, 2018.

[31] G.Weber and P. Brusilovsky, "ELM-ART: A Versatile Adaptive System for Web- based instruction," International Journal of Artificial Intelligence in Education (IJAIED), 2001, 12, pp.351384. 〈hal-00197328〉 Retrieved from https://bit.ly/2LzBQdJ, 2001.

[32] M.Wade, Danis, Dirk De Clercq and Olga Petricevic, "Are social networks more important for new business activity in emerging than developed economies? An empirical extension,” International Business Review, Vol.20, No.4, 2011, pp. 394-408, ISSN 09695931. Retrieved from https://bit.ly/3431O34, 2010.

[33] J.Woodruff, "Role of Finance in a Business," Retrieved from https://bit.ly/2maRBig, 2019.

[34] F. Yi-ping, F. Jie F., S. Mao-ying and S. Meng-qiang, "Sensitivity of livelihood strategy to livelihood capital in mountain areas: Empirical analysis based on different settlements in the upper reaches of the Minjiang River, China, Ecological Indicators, Vol.38, 2014, pp. 225-235, ISSN 1470-160X. Retrieved from https://bit.ly/37aUzZ1, 2014. 